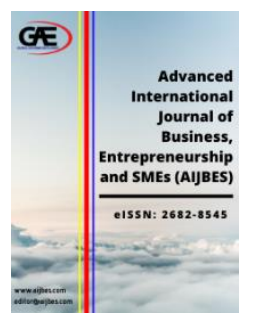

\author{
ADVANCED INTERNATIONAL JOURNAL OF \\ BUSINESS, ENTREPRENEURSHIP AND SMES \\ (AIJBES) \\ www.aijbes.com
}

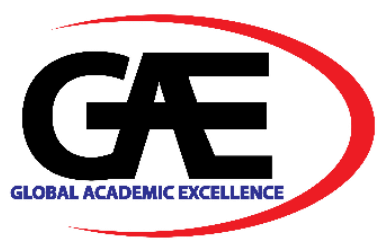

\title{
THE AFFECTING FACTORS ON ONLINE CLOTHING PURCHASE: A CONCEPTUAL MODEL
}

\author{
Annisa Purwaningtyas ${ }^{1 *}$, Raden Aswin Rahadi ${ }^{2}$ \\ 1 School of Business and Management, Institut Teknologi Bandung, Indonesia \\ Email: annisa_purwaningtyas@sbm-itb.ac.id \\ 2 School of Business and Management, Institut Teknologi Bandung, Indonesia \\ Email: aswin.rahadi@sbm-itb.ac.id \\ Corresponding Author
}

\section{Article Info:}

Article history:

Received date: 31.01 .2021

Revised date: 07.02.2021

Accepted date: 06.06.2021

Published date: 15.06.2021

To cite this document:

Purwaningtyas, A., \& Rahadi, R. A. (2021). The Affecting Factors on Online Clothing Purchase: A Conceptual Model. Advanced International Journal of Business, Entrepreneurship and SMEs, 3 (8), 8697.

DOI: $10.35631 / A I J B E S .38006$.

This work is licensed under $\mathrm{CC}$ BY 4.0

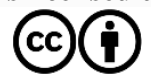

\begin{abstract}
:
The aim of this study is to discuss the factors affecting people's clothing purchases through online channels. There are various online clothing channels in Indonesia, appearing in form of e-commerce platforms, online stores, even social media has become a place for people to trade goods. For this research, a synthesize of 36 papers was made from past literature reviews. The analysis and discussion result shows the factors affecting people's online clothing purchase decision are price, promotion, product design/style, product quality, brand image, information availability, seller trustworthiness, product variety, ease of use, and service quality. These factors influence the purchase decision of the customers when they shop for clothing through online channels. The limitation of this research is only covering clothing online purchases. The result and findings from this study will be useful for clothing brand owners or managers, e-commerce platforms in Jakarta, Indonesia. In the future, a quantitative research method can be conducted to further explore this study and improve the findings of this study.
\end{abstract}

Keywords:

Clothing, Fashion, Purchase, E-commerce, Consumer Preference, Jakarta

\section{Introduction}

Clothing is one of the basic needs of humans. People wear different clothes for different occasions, from daily comfortable clothes to formal clothes vary according to the needs and the one's preference. Clothes serves multiple functions such as protection from the environment or hazard, providing a barrier from cold or heat also from possible toxic materials, also to improve the ease of the wearer in doing their daily activities. Beside its functionality 
Volume 3 Issue 8 (June 2021) PP. 86-97

DOI 10.35631/AIJBES.38006

clothing, clothes might also serve as an expression of personal taste, character, and style to the world.

People used to shop the traditional way at retail shops or boutiques to get their clothing. With the development and improvement of technology and internet, all kind of products are available for purchase online which became a new way of shopping for people across the world. According to Statista, the revenue of Indonesia's apparel market reached 14,026 million USD which was 23\% lower than it was in the previous year, and it is projected that in 2021 the number would reach 16,423 million USD. The drop of revenue is predicted to occur as the recent outbreak affects various segments across the world.

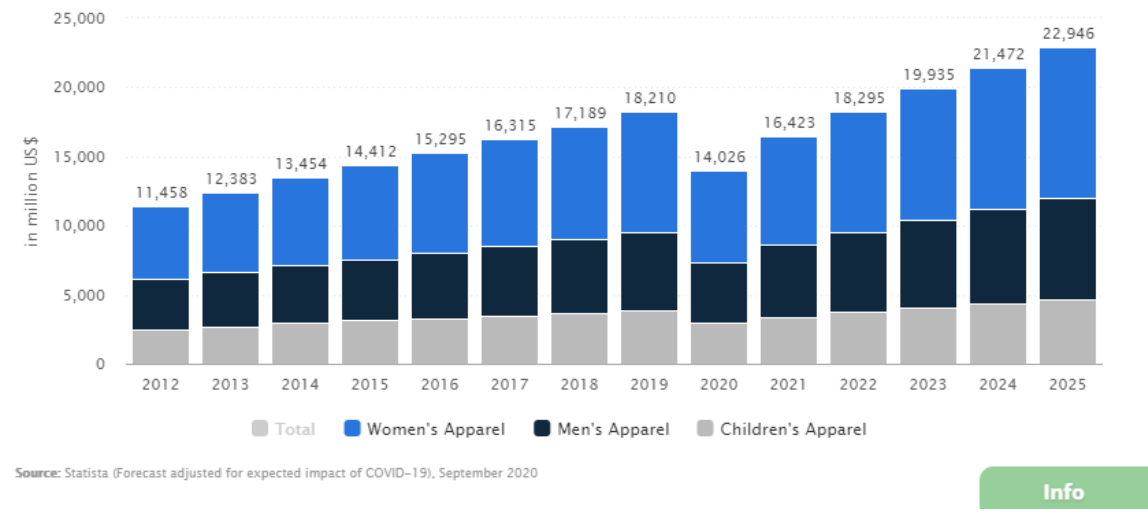

Figure 1: Indonesia Apparel Market Revenue

Source: (Statista. September 2020)

During the COVID-19 pandemic, a lot of aspects were affected by the changes happened while adjusting to the new custom. In the report published by Bank of Indonesia the domestic retail sales of clothing for October 2020 decreased by 58.1 compared to the previous year (Indonesia, 2014). In a report by McKinsey\&Company, titled "Optimistic, digital, generous: COVID-19's impact on Indonesian consumer sentiment", it is stated that there is a $61 \%$ drop in consumers' net intent to spend on apparel category from the survey in April 2020 (Dahiya and Potia, 2020). In the same report, it is stated that they are likely to purchase apparel from online channels over offline channels. This shows a potential for brands to start focusing and exploring their online channels to attract more customers. While a lot of retailers had to adjust and decrease their open time and some other need to go as far as closing their stores during the pandemic, online channels are becoming the alternatives for people to shop for their needs.

This study aims to understand the factors affecting online clothing purchase decision. One of the challenges of selling products through online channels is, unlike offline shops customers can not feel or try the product directly. It becomes important to provide products that will satisfy the customers and to present them nicely in the channels so the customers can get the right idea about the products. Knowing what factors are considered when purchasing clothing through online channels will help sellers to better highlight their product's features.

\section{Literature}

\section{Consumer Preference}

Consumer preference can be defined as the subjective taste of an individual measured by their satisfaction after they have purchased the item which is referred by the term utility. This preference allows consumer to put a rank on a set of goods according to the utility it projects. Copyright $\odot$ GLOBAL ACADEMIC EXCELLENCE (M) SDN BHD - All rights reserved 
Volume 3 Issue 8 (June 2021) PP. 86-97 DOI 10.35631/AIJBES.38006

According to Venkatraman et al. (2012), Consumers' preferences for products or brands arise from the combination of many different factors. Some factors come from features of the product itself (e.g., price, durability), while others are attributes of consumers themselves (e.g., goals, attitudes, discretionary income). Although consumer preference does not guarantee their choice and future behavior, understanding the preference gives us a preview of the general picture of the consumers' wants so that we can give and provide better products or services.

\section{E-commerce}

E-commerce is the activity of buying and selling of products done electronically, such as through websites, mobile applications, and conversational commerce. EC provides new channels for the global marketing of tangible goods and presents opportunities to create new businesses providing information and other knowledge-based intangible products (Gunasekaran et al., 2002)

\section{Price}

Price is one of the most important aspects in every commerce which matters to both consumer and seller. With the current state of technology \& information, customers easily obtained information on products or service alternatives. Consumers are very rational to judge what they are getting from buying a product or service in exchange of their payments for it (Al-Mamun, Rahman and Robel, 2014). In a previous research by Islam (2018) stated that online marketing activities and the pricing strategy seem to have the most vital role in creating purchase intention in online clothing shops cases (Islam, 2018).

\section{Product Quality}

Product quality can be defined as the ability of a product to meets the standard of the requirements from the user. A product with good quality should be able to function without problems. Consumers' judgment on a product's performance is called the perceived quality, which is more relatable in online shopping cases. In online purchase cases, as consumers can not directly, they rely more on informational cues they can gather. In a study by Swinker and Hines (2006) $65 \%$ of the respondents agree that quality is an important criterion in making clothing purchase decisions. An analysis of the data indicated that $75 \%$ of the informational cues and $36 \%$ of the expectations of a high-quality garment were used by the respondents when considering the quality of a garment (Swinker and Hines, 2006).

\section{Product Design/Style}

The product trait itself plays a part in consumers' purchase decisions. Customers gave high priority for availability of latest designs, availability of options, shopping for middle class, convenience of choice and family shopping under one roof (Hari and Prasad, 2014). Clothing design covers more about the making process, types of fitting, cuts, length, and other clothing attributes, while the style pays more attention towards the color and pattern of the clothing.

\section{Brand Image}

Brand image is a set of perceptions that customer has on a product which is reflected by the brand association. The strength of a brand rests in its value acquired through tangible attributes like pertinence of brand name and associated benefits thereof. Consumers perceive the brand on dimensions that typically capture a person's personality, and extend that to the domain of brands (Rajagopal, 2006) 


\section{Promotion}

Promotion is promotional techniques run by stores to attract customers. Studies by (Krishnakumar et al., 2013; Islam, 2018; Lee and Chen-Yu, 2018; Fachmi, Setiawan and Hidayat, 2019; Shinnaranantana, 2019) showed that promotional activities such as discounts or special offers affect positively towards purchase decision.

\section{Information Availability}

Information available about a product can give customers better understanding that can help them generate the idea how the product would be. In accordance with the theory of consumer behavior, product knowledge is part of the decision-making process, so it is said that product knowledge can influence purchasing decisions (Rachmawati, 2018). Providing necessary reliable information about the products should affect positively to the purchase decision.

\section{Ease of Use}

In the context of online shopping, the ease of use of the application or platforms and the mechanism of purchase become an aspect that boost the consumers' convenience. The results of a study by Weng and Ding, 2014, indicate that perceived usefulness, perceived ease of use and perceived risk all have a significant relationship with consumer attitudes, which subsequently has a significant effect on intention to use online group buying sites (Weng and Ding, 2014).

\section{Seller Trustworthiness}

Trust is an important element in economic activity, especially in the case of online shopping which has less direct interaction between customers and sellers. Utz, Kerkhof and van den Bos (2012) did an experiment that show clearly that consumer reviews do not only influence product choice, but also the perceived trustworthiness of an online store and consequently possibly also choice of an online store (Utz, Kerkhof and van den Bos, 2012).

\section{Product Variety}

Product variety is the number of assortment or selection of products available for customers to choose. Studies done by (Batra, 2014; Hari and Prasad, 2014; Alamelu, 2018; Shinnaranantana, 2019) showed that product variety affects consumer purchase decision. However, another study by Heitmann, Herrmann and Kaiser, (2007) shows result that there is a negative link between variety and purchase probability for high variety assortments.

\section{Service Quality}

Service quality can be addressed as the excellence provided by a company or seller. In terms of online services, results from a study by Rita, et. al, (2019) showed that three dimensions of e-service quality, namely website design, security/privacy and fulfilment affect overall eservice quality and overall e-service quality is statistically significantly related to customer behavior (Rita, Oliveira and Farisa, 2019).

\section{Discussion}

Gathering the information from the preliminary interview and literature review, ten factors affecting consumers' decision in purchasing clothing from online shops. Comparing factors obtained from literature review and from interviewing respondents who had shopped at least once in the last 3 months gives the following factors: Price, Product Quality, Product Design/Style, Brand Image, Promotion, Information Availability, Ease of Use, Seller/Store Trustworthiness, Product Variety, and Service Quality. 
Volume 3 Issue 8 (June 2021) PP. 86-97

DOI 10.35631/AIJBES.38006

Product Design/Style and Price are two factors that are mentioned as important by all respondents. Both factors are included in the top four factors considered by the respondents when purchasing clothing products. Some of the respondents already set a certain budget on their expenditure for clothing and some of them already had the desired product in mind prior purchase. Following next, promotion is chosen to be an important factor to consider. Products with discounts or special offers usually get extra exposure and might attract more consumers' attention. Promotions can be in various forms from extra discounts, vouchers, Buy One get One, and a lot more special offers that would give the impression of more value acquired through that purchase.

The next factor is product quality, which in the online experience is more suitable to be referred to as the perceived product quality. As customers can not directly touch or feel to assess the product quality, customers can instead gather available descriptions or information about the products and information from their previous knowledge. Consumer reviews and words-ofmouth can also be a source of the product knowledge that can help customers to assess the product quality.

Seller Trustworthiness is the next factor considered to be important in choosing respondent's clothing. Shopping in the more trusted shops or e-commerce gives more assurance about the safety of the transaction. Nowadays people should be able to review online stores in many ecommerce platforms which could give customers some assurance about their reliability.

Product quality is another factor that both appear in the literature review and from the interview result. In online shopping cases, customers can not directly see and feel the product to know the quality, however, customers can refer to the provided information or description about the product to get more information about its quality. Customers' review can also help give fellow customers more realistic information and details about the purchased product and gives a better projection of the product quality to customers' perceived product quality. The next factor is related to the perceived product quality, which is the information availability. Providing complete and helpful information is a good way to present the product better in online shops. Information related to the products such as sizing charts, material description, garment care instruction and more will be helpful for customers when seeing the product displayed.

Other factors mentioned in the literature reviews are brand image, ease of use and service quality. Brand is also mentioned by a couple of respondents during the interview even though not as often as the previously discussed factors. Ease of use and service quality can be considered as part of the features of e-commerce. To make it clearer all the features will be categorized as two main factors, product related factors and e-commerce related factors.

Product related factors will consist of price, product design/style, promotion, product quality, and brand image. While the e-commerce related factors will have factors such as information availability, seller trustworthiness, product variety, ease of use, and service quality.

\section{Methodology}

This study is pursued by an analysis of literature review covering 36 papers related to the topic which is synthesized in the next part. These literature studies are used to help generate a conceptual framework that will be presented at the end of this paper. A preliminary interview to 11 respondents who had shopped at least once in the last three months also done to further confirm these factors. This conceptual framework could be helpful for but not limited to brands, 
Volume 3 Issue 8 (June 2021) PP. 86-97 DOI 10.35631/AIJBES.38006

online stores, online platforms, and other researchers in Indonesia. After collecting factors from both sources, ten factors, divided into two categories, collected as factors that affect online clothing purchase decisions.

\section{Analysis}

From the review of the previous research, ten factors, which are price, promotion, product design/style, product quality, brand image, information availability, seller trustworthiness, product variety, ease of use and service quality, has been consistently found to be affecting online clothing purchase decision. This section will present the literature synthesis of the study for each key factor mentioned.

\begin{tabular}{|c|c|}
\hline Price & $\begin{array}{l}\text { 1. Shinnaranantana, N. (2019) 'Internet Shopping and Buying Behavior of } \\
\text { Clothing and Accessories By Young Single Consumer in Bangkok, Thailand', in } \\
\text { Proceedings of the 43rd International Academic Conference, Lisbon. } \\
\text { International Institute of Social and Economic Sciences. doi: } \\
\text { 10.20472/iac.2018.043.042. }\end{array}$ \\
\hline & $\begin{array}{l}\text { 2. Thangavel, S. and P, A. (2017) 'A Study on Consumer Preference and } \\
\text { Satisfaction of Branded Clothing of Men - With Special Reference to Coimbatore } \\
\text { City', PARIPEX - INDIAN JOURNAL OF RESEARCH, 6(1), pp. 821-823. }\end{array}$ \\
\hline & $\begin{array}{l}\text { 3. Alamelu, D. (2018) 'A Study on the Attributes Influencing the Purchasing } \\
\text { behaviour of Apparel Consumer in Organized Retail with Special Reference to } \\
\text { Max Retail Division', International Journal of Management Studies, V(3(4)), p. } \\
\text { 92. doi: } 10.18843 / \text { ijms/v5i3(4)/10. }\end{array}$ \\
\hline & $\begin{array}{l}\text { 4. Batra, A. (2014) 'Factors Influencing Consumer Purchase Decisions at } \\
\text { Organized Retail Stores in New Delhi', International Journal of Innovative } \\
\text { Research and \& Development. }\end{array}$ \\
\hline & $\begin{array}{l}\text { 5. Nasution, M. D. T. P. et al. (2019) 'An empirical examination of the factors } \\
\text { influencing consumer's purchase intention toward online shopping', Journal of } \\
\text { Business \& Retail Management Research, 13(04), pp. 13-29. doi: } \\
\text { 10.24052/JBRMR/V13IS04/ART-02. }\end{array}$ \\
\hline & $\begin{array}{l}\text { 6. Cham, T. H. et al. (2018) 'Factors influencing clothing interest and purchase } \\
\text { intention: a study of Generation Y consumers in Malaysia', The International } \\
\text { Review of Retail, Distribution and Consumer Research, 28(2), pp. 174-189. doi: } \\
10.1080 / 09593969.2017 .1397045 \text {. }\end{array}$ \\
\hline & $\begin{array}{l}\text { 7. Widyastuti, S. and Said, M. (2017) 'Consumer consideration in purchase } \\
\text { decision of SPECS sports shoes product through brand image, product design and } \\
\text { price perception', International Journal of Supply Chain Management, 6(4), pp. } \\
\text { 199-207. }\end{array}$ \\
\hline & $\begin{array}{l}\text { 8. Islam, T. (2018) 'Factors Affecting Consumer Purchase Behavior Towards } \\
\text { Online Clothing Products in Bangladesh', SSRN Electronic Journal. doi: } \\
\text { 10.2139/ssrn.3286105. }\end{array}$ \\
\hline Product & 1. Cho, S. (2017) 'Millennial Men' s Shopping Orientation for Apparel : \\
\hline Design/Style & $\begin{array}{l}\text { Comparison of Korean and American Consumers', International Textile and } \\
\text { Apparel Association Annual Conference Proceedings, 74(1), pp. 1-3. }\end{array}$ \\
\hline & $\begin{array}{l}\text { 2. Thangavel, S. and P, A. (2017) 'A Study on Consumer Preference and } \\
\text { Satisfaction of Branded Clothing of Men - With Special Reference to Coimbatore } \\
\text { City', PARIPEX - INDIAN JOURNAL OF RESEARCH, 6(1), pp. } 821-823 \text {. }\end{array}$ \\
\hline
\end{tabular}


Volume 3 Issue 8 (June 2021) PP. 86-97

DOI 10.35631/AIJBES.38006

\begin{tabular}{|c|c|}
\hline & $\begin{array}{l}\text { 3. Alamelu, D. (2018) 'A Study on the Attributes Influencing the Purchasing } \\
\text { behaviour of Apparel Consumer in Organized Retail with Special Reference to } \\
\text { Max Retail Division', International Journal of Management Studies, V(3(4)), p. } \\
\text { 92. doi: } 10.18843 / \text { ijms/v5i3(4)/10. }\end{array}$ \\
\hline & $\begin{array}{l}\text { 4. Hari, G. and Prasad, S. (2014) 'Factors Influencing Buying Behavior of a } \\
\begin{array}{l}\text { Selected } \\
\text { Annual Research Journal of SCMS, }\end{array} \text { (1), pp. 41-55. }\end{array}$ \\
\hline & $\begin{array}{l}\text { 5. Koca, E. and Koc, F. (2016) 'A Study of Clothing Purchasing Behavior By } \\
\text { Gender with Respect to Fashion and Brand Awareness', European Scientific } \\
\text { Journal, ESJ, 12(7), p. 234. doi: 10.19044/esj.2016.v12n7p234. }\end{array}$ \\
\hline & $\begin{array}{l}\text { 6. Rahman, O. et al. (2018) 'A study of apparel consumer behaviour in China and } \\
\text { Taiwan', International Journal of Fashion Design, Technology and Education. } \\
\text { Taylor \& Francis, 11(1), pp. 22-33. doi: 10.1080/17543266.2017.1298158. }\end{array}$ \\
\hline & $\begin{array}{l}\text { 7. Anoop, V. (2004) A STUDY ON CUSTOMER PREFERENCE ON T-SHIRT. } \\
\text { KONGU ENGINEERING COLLEGE, PERUNDURAI. Thesis. }\end{array}$ \\
\hline Prom & $\begin{array}{l}\text { 1. Shinnaranantana, N. (2019) 'Internet Shopping and Buying Behavior of } \\
\text { Clothing and Accessories By Young Single Consumer in Bangkok, Thailand', in } \\
\text { Proceedings of the 43rd International Academic Conference, Lisbon. } \\
\text { International Institute of Social and Economic Sciences. doi: } \\
\text { 10.20472/iac.2018.043.042. }\end{array}$ \\
\hline & $\begin{array}{l}\text { 2. Fachmi, M., Setiawan, I. P. and Hidayat, A. (2019) 'Analysis of Factors } \\
\text { Affecting Consumer Purchase Decision at Online Shops', International Journal of } \\
\text { Innovative Science and Research Technology, (July), pp. 0-4. doi: } \\
\text { 10.31219/osf.io/egysw. }\end{array}$ \\
\hline & $\begin{array}{l}\text { 3. Krishnakumar, K. B. G. M. et al. (2013) 'Factors Influencing Apparel Buying } \\
\text { Behaviour in India : A Measurement Model tics , reference groups , store } \\
\text { attributes, product attributes .', Paripex - Indian Journal of Research, 2(3), pp. } \\
218-224 \text {. }\end{array}$ \\
\hline & $\begin{array}{l}\text { 4. Lee, J. E. and Chen-Yu, J. H. (2018) 'Effects of price discount on consumers' } \\
\text { perceptions of savings, quality, and value for apparel products: mediating effect } \\
\text { of price discount affect', Fashion and Textiles. Springer Singapore, 5(1), p. } 13 \text {. } \\
\text { doi: } 10.1186 / \mathrm{s} 40691-018-0128-2 \text {. }\end{array}$ \\
\hline & $\begin{array}{l}\text { 5. Islam, T. (2018) 'Factors Affecting Consumer Purchase Behavior Towards } \\
\text { Online Clothing Products in Bangladesh', SSRN Electronic Journal. doi: } \\
\text { 10.2139/ssrn.3286105. }\end{array}$ \\
\hline $\begin{array}{l}\text { Product } \\
\text { Quality }\end{array}$ & 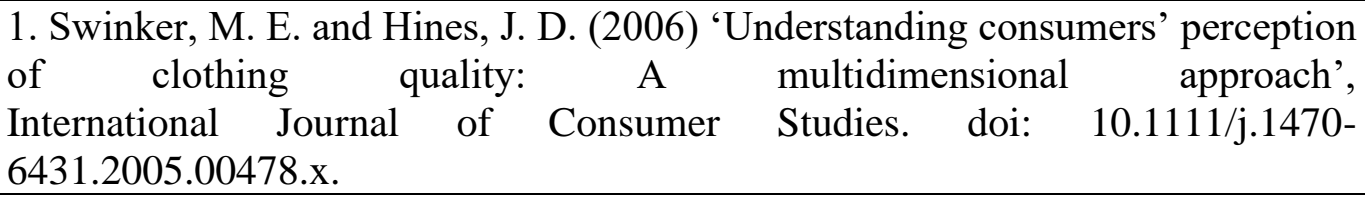 \\
\hline & $\begin{array}{l}\text { 2. Sarmad, I. (2015) 'Factor Affecting Consumer Purchase Intention toward } \\
\text { Multinational Apparel } \\
\text { Journal of Basic and Applied Scientific Research, 5(6), pp. 1-6. Available at: } \\
\text { http://textroad.com/pdf/JBASR/J. Basic. Appl. Sci. Res., 5(6)1-6, 2015.pdf. }\end{array}$ \\
\hline & 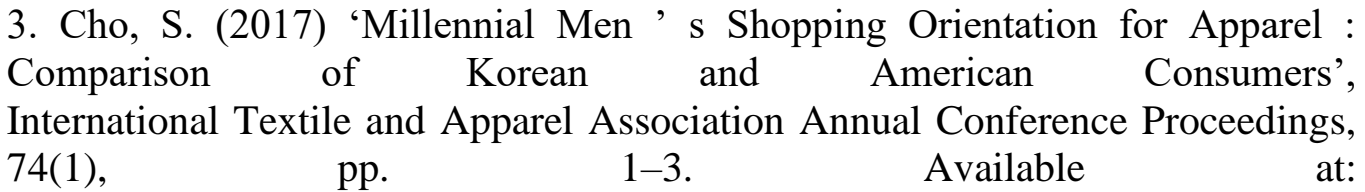 \\
\hline
\end{tabular}


Volume 3 Issue 8 (June 2021) PP. 86-97

DOI 10.35631/AIJBES.38006

\begin{tabular}{|c|c|}
\hline \multirow[t]{5}{*}{ 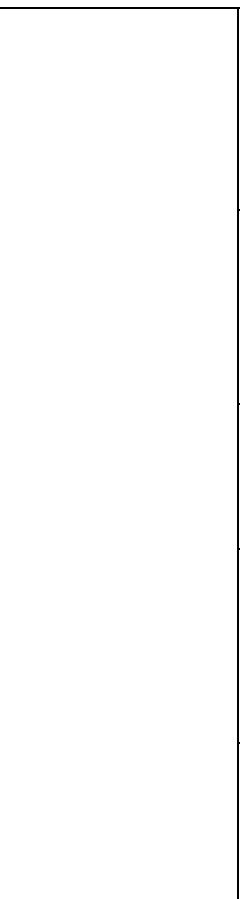 } & $\begin{array}{l}\text { https://lib.dr.iastate.edu/cgi/viewcontent.cgi?article=2327\&context=itaa_procee } \\
\text { dings }\end{array}$ \\
\hline & $\begin{array}{l}\text { 4. Thangavel, S. and P, A. (2017) 'A Study on Consumer Preference and } \\
\text { Satisfaction of Branded Clothing of Men - With Special Reference to Coimbatore } \\
\text { City', } \\
\text { PARIPEX - INDIAN JOURNAL OF RESEARCH, } 6(1) \text {, pp. } 821-823 \text {. }\end{array}$ \\
\hline & $\begin{array}{l}\text { 5. Azevedo, S. et al. (2008) 'Consumer Buying Behaviour in Fashion Retailling: } \\
\text { Empirical } \\
\text { SSRN Electronic Journal, (March 2018). doi: 10.2139/ssrn.1303718. }\end{array}$ \\
\hline & $\begin{array}{l}\text { 8. Anoop, V. (2004) A STUDY ON CUSTOMER PREFERENCE ON T-SHIRT. } \\
\text { KONGU ENGINEERING COLLEGE, PERUNDURAI. Thesis. } \\
\text { Available at: https://www.scribd.com/document/51784420/a-study-on-customer- } \\
\text { preference-on-t-shirt. }\end{array}$ \\
\hline & $\begin{array}{l}\text { 9. Susanto, H. (2016) THE EFFECT OF BRAND IMAGE, PRODUCT } \\
\text { QUALITY AND PRICE TOWARD PURCHASE DECISION. Thesis. } \\
\text { MUHAMMADIYAH UNIVERSITY OF SURAKARTA. }\end{array}$ \\
\hline \multirow[t]{3}{*}{$\begin{array}{l}\text { Brand } \\
\text { Image }\end{array}$} & $\begin{array}{l}\text { 1. Saeed, R. et al. (2013) 'Factors affecting consumer purchase decision in } \\
\text { clothing industry of Sahiwal, Pakistan', World Applied Sciences Journal, 24(7), } \\
\text { pp. } 844-849 \text {. doi: 10.5829/idosi.wasj.2013.24.07.1339. }\end{array}$ \\
\hline & $\begin{array}{l}\text { 2. Susanto, H. (2016) THE EFFECT OF BRAND IMAGE, PRODUCT } \\
\text { QUALITY AND PRICE TOWARD PURCHASE DECISION. Thesis. } \\
\text { MUHAMMADIYAH UNIVERSITY OF SURAKARTA. }\end{array}$ \\
\hline & $\begin{array}{l}\text { 3. Cham, T. H. et al. (2018) 'Factors influencing clothing interest and purchase } \\
\text { intention: a study of Generation Y consumers in Malaysia', The International } \\
\text { Review of Retail, Distribution and Consumer Research, 28(2), pp. 174-189. doi: } \\
\text { 10.1080/09593969.2017.1397045. }\end{array}$ \\
\hline \multirow[t]{3}{*}{$\begin{array}{l}\text { Information } \\
\text { Availability }\end{array}$} & $\begin{array}{l}\text { 1. Katawetawaraks, C. and Wang, C. L. (2011) 'Online Shopper Behavior: } \\
\text { Influences of } \\
\text { Asian Journal of Business Research, 1(2), pp. 66-74. }\end{array}$ \\
\hline & $\begin{array}{l}\text { 2. Cham, T. H. et al. (2018) 'Factors influencing clothing interest and purchase } \\
\text { intention: a study of Generation Y consumers in Malaysia', The International } \\
\text { Review of Retail, Distribution and Consumer Research, 28(2), pp. 174-189. doi: } \\
\text { 10.1080/09593969.2017.1397045. }\end{array}$ \\
\hline & $\begin{array}{l}\text { 3. Chen, Y.-C. et al. (2017) 'Online apparel shopping behavior: Effects of } \\
\text { consumer information search on purchase decision making in the digital age', } \\
\text { in } 2017 \text { IEEE 8th International Conference on Awareness Science and } \\
\text { Technology (iCAST). IEEE, pp. 143-148. doi: 10.1109/ICAwST.2017.8256434. }\end{array}$ \\
\hline $\begin{array}{c}\text { Seller } \\
\text { Trust- } \\
\text { worthiness }\end{array}$ & $\begin{array}{l}\text { 1. Fachmi, M., Setiawan, I. P. and Hidayat, A. (2019) 'Analysis of Factors } \\
\text { Affecting Consumer Purchase Decision at Online Shops', International Journal of } \\
\text { Innovative Science and Research Technology, (July), pp. 0-4. doi: } \\
\text { 10.31219/osf.io/egysw. }\end{array}$ \\
\hline
\end{tabular}


Volume 3 Issue 8 (June 2021) PP. 86-97

DOI 10.35631/AIJBES.38006

\begin{tabular}{|c|c|}
\hline & $\begin{array}{l}\text { 2. Limpo, L. and Meryana (2017) 'Effect of Trust and Easy on Decision Online } \\
\text { Purchase toward Special Fashion Products', International Journal of Science and } \\
\text { Research (IJSR), 6(10), pp. 715-717. doi: } 10.21275 / \text { ART20177118. }\end{array}$ \\
\hline & $\begin{array}{l}\text { 3. Büttner, O. B. and Göritz, A. S. (2008) 'Perceived trustworthiness of online } \\
\text { shops', } \\
\text { Journal of Consumer Behaviour, 7(1), pp. 35-50. doi: 10.1002/cb.235. }\end{array}$ \\
\hline & $\begin{array}{l}\text { 4. Utz, S., Kerkhof, P. and van den Bos, J. (2012) 'Consumers rule: How } \\
\text { consumer reviews influence perceived trustworthiness of online stores', } \\
\text { Electronic Commerce Research and Applications. Elsevier B.V., 11(1), pp. 49- } \\
\text { 58. doi: } 10.1016 / \text { j.elerap.2011.07.010. }\end{array}$ \\
\hline & $\begin{array}{l}\text { 1. Shinnaranantana, N. (2019) 'Internet Shopping and Buying Behavior of } \\
\text { Clothing and Accessories By Young Single Consumer in Bangkok, Thailand', in } \\
\text { Proceedings of the 43rd International Academic Conference, Lisbon. } \\
\text { International Institute of Social and Economic Sciences. doi: } \\
\text { 10.20472/iac.2018.043.042. }\end{array}$ \\
\hline & $\begin{array}{l}\text { 2. Alamelu, D. (2018) 'A Study on the Attributes Influencing the Purchasing } \\
\text { behaviour of Apparel Consumer in Organized Retail with Special Reference to } \\
\text { Max Retail Division', International Journal of Management Studies, V(3(4)), p. } \\
\text { 92. doi: } 10.18843 / \mathrm{ijms} / \mathrm{v} 5 \mathrm{i} 3(4) / 10 \text {. }\end{array}$ \\
\hline & 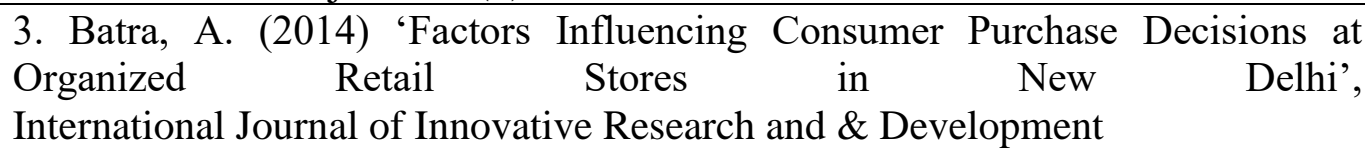 \\
\hline & $\begin{array}{l}\text { 4. Hari, G. and Prasad, S. (2014) 'Factors Influencing Buying Behavior of a } \\
\text { Selected Apparel Retailer's Customers', Annual Research Journal of SCMS, 1(1), } \\
\text { pp. 41-55. }\end{array}$ \\
\hline Ease of Use & $\begin{array}{l}\text { 1. Khare, A. (2016) 'Consumer Shopping Styles and Online Shopping: An } \\
\text { Empirical Study of Indian Consumers', Journal of Global Marketing, 29(1), pp. } \\
\text { 40-53. doi: } 10.1080 / 08911762.2015 .1122137 \text {. }\end{array}$ \\
\hline & $\begin{array}{l}\text { 2. Indriani, I. (2016) 'Analysis the Factors Influence Consumer Buying Decision } \\
\text { on Online Shopping Clothing for Consumer in Manado', Jurnal Riset Ekonomi, } \\
\text { Manajemen, Bisnis dan Akuntansi, 4(1), pp. 1166-1177. doi: } \\
\text { 10.35794/emba.v4i1.11874. }\end{array}$ \\
\hline $\begin{array}{l}\text { Service } \\
\text { Quality }\end{array}$ & $\begin{array}{l}\text { 1. Fachmi, M., Setiawan, I. P. and Hidayat, A. (2019) 'Analysis of Factors } \\
\text { Affecting Consumer Purchase Decision at Online Shops', International Journal of } \\
\text { Innovative Science and Research Technology, (July), pp. 0-4. doi: } \\
\text { 10.31219/osf.io/egysw. }\end{array}$ \\
\hline & $\begin{array}{l}\text { 2. Indriani, I. (2016) 'Analysis the Factors Influence Consumer Buying Decision } \\
\text { on Online Shopping Clothing for Consumer in Manado', Jurnal Riset Ekonomi, } \\
\text { Manajemen, Bisnis dan Akuntansi, 4(1), pp. 1166-1177. doi: } \\
\text { 10.35794/emba.v4i1.11874. }\end{array}$ \\
\hline
\end{tabular}

\section{Table 1: Previous Research on Online Clothing Purchase}

Source: (Author's Analysis)

\section{Conclusion}

Based on the discussion above, the online clothing purchase decision can be affected by ten factors that customers consider before making the purchase. The ten factors are price, promotion, product design/style, product quality, brand image, information availability, seller 
Volume 3 Issue 8 (June 2021) PP. 86-97

DOI 10.35631/AIJBES.38006

trustworthiness, product variety, ease of use and service quality which directly or indirectly affects the purchase decision making process.

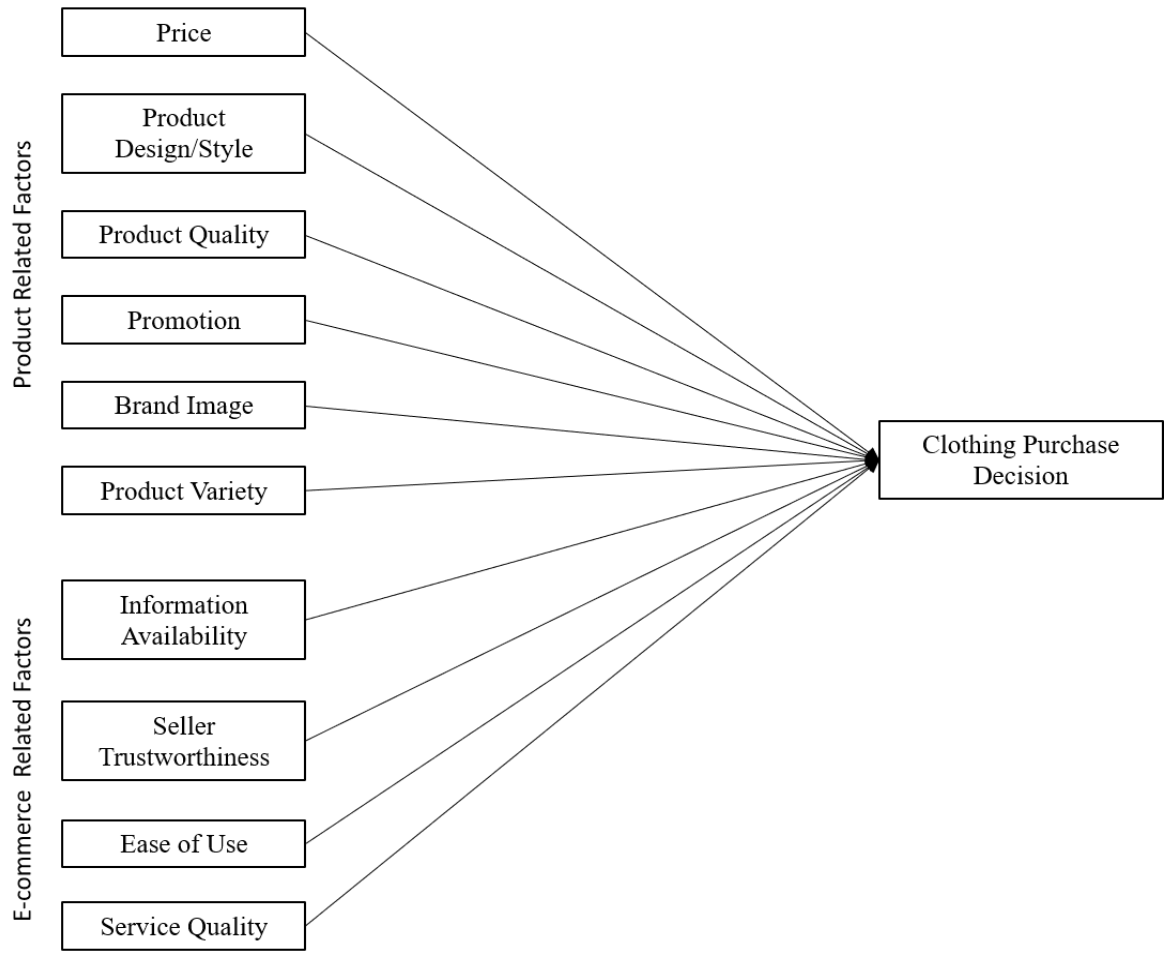

Figure 2: Conceptual Model

Source: (Author's Analysis)

The result from this study can be used by brand owners, online stores, and other e-commerce platforms to determine their pricing and marketing strategies. Clothing brand owners should focus on producing high-quality products which follows the current fashion trend, and the right pricing strategy should be applied to boost their sales. Beside pricing strategy, additional promotions should attract more customers to purchase their products. Managing the brand's image also becomes important to attract more customers, this might be done by continuously providing good products and maintaining its social media presence to engage more customers. E-commerce platforms should pay attention to the overall performance and focus on factors such as, information availability, seller trustworthiness, ease of use, and service quality. Providing an accurate information about the product sold on the platform is important to avoid any misleading advertising. Making sure the sellers abide the rules and giving the best product and service for the customers is also a key in providing a safe shopping experience. Continuously improving the user interface and keeping it simple yet engaging might give customers a pleasant experience while using the site or platforms while shopping online. Managing the overall service quality provided by the e-commerce should be beneficial for the long run.

\section{Future Research}

Online shopping has become so big in the last few years and will likely to continue growing in the future. There are a lot of topics that can be raise for future research. Next research may explore more on each individual factor effect on purchase decision or even to a selected case using a real example of e-commerce platform. For example, analysing various pricing strategies towards customers' online clothing purchase decision or analysing the seasonal 
Volume 3 Issue 8 (June 2021) PP. 86-97 DOI 10.35631/AIJBES.38006

shopping behaviour in Indonesia to see the deeper relation between big shopping events, promotions, and customers' purchase decision. A broader scale of data gathering may be needed to understand the consumers' clothing purchase decision in Indonesia.

\section{References}

Al-Mamun, A., Rahman, M. K. and Robel, S. D. (2014) 'A Critical Review of Consumers' Sensitivity to Price: Managerial and Theoretical Issues Understanding Muslim Medical Tourists' Perceptions View project Dermatology View project', Journal of International Business and Economics, 2(2), pp. 1-9

Alamelu, D. (2018) 'A Study on the Attributes Influencing the Purchasing behaviour of Apparel Consumer in Organized Retail with Special Reference to Max Retail Division', International Journal of Management Studies, V(3(4)), p. 92. doi: 10.18843/ijms/v5i3(4)/10.

Batra, A. (2014) 'Factors Influencing Consumer Purchase Decisions at Organized Retail Stores in New Delhi', International Journal of Innovative Research and \& Development.

Dahiya, K. and Potia, A. (2020) 'Optimistic, Digital, Generous: COVID-19's Impact on Indonesian Consumer Sentiment', Mc Kinsey \& Company

Fachmi, M., Setiawan, I. P. and Hidayat, A. (2019) 'Analysis of Factors Affecting Consumer Purchase Decision at Online Shops', International Journal of Innovative Science and Research Technology, (July), pp. 0-4. doi: 10.31219/osf.io/egysw.

Gunasekaran, A. et al. (2002) 'E-commerce and its impact on operations management', International Journal of Production Economics, 75(1-2), pp. 185-197. doi: 10.1016/S0925-5273(01)00191-8.

Hari, G. and Prasad, S. (2014) 'Factors Influencing Buying Behavior of a Selected Apparel Retailer's Customers', Annual Research Journal of SCMS, 1(1), pp. 41-55.

Heitmann, M., Herrmann, A. and Kaiser, C. (2007) 'The effect of product variety on purchase probability', Review of Managerial Science, 1(2), pp. 111-131. doi: 10.1007/s11846007-0006-6. Indonesia, B. (2014) Survei Penjualan Eceran (Maret, 2014

Islam, T. (2018) 'Factors Affecting Consumer Purchase Behavior Towards Online Clothing Products in Bangladesh', SSRN Electronic Journal. doi: 10.2139/ssrn.3286105.

Krishnakumar, K. B. G. M. et al. (2013) 'Factors Influencing Apparel Buying Behaviour in India: A Measurement Model tics, reference groups, store attributes, product attributes .', Paripex - Indian Journal of Research, 2(3), pp. 218-224.

Lee, J. E. and Chen-Yu, J. H. (2018) 'Effects of price discount on consumers' perceptions of savings, quality, and value for apparel products: mediating effect of price discount affect', Fashion and Textiles. Springer Singapore, 5(1), p. 13. doi: 10.1186/s40691018-0128-2.

Rachmawati, E. (2018) 'Product Knowledge Review on the Purchase Decision', 231(Amca), pp. 338-340. doi: 10.2991/amca-18.2018.92.

Rajagopal (2006) 'Brand excellence: Measuring the impact of advertising and brand personality on buying decisions', Measuring Business Excellence, 10(3), pp. 56-65. doi: 10.1108/13683040610685793.

Rita, P., Oliveira, T. and Farisa, A. (2019) 'The impact of e-service quality and customer satisfaction on customer behavior in online shopping', Heliyon. Elsevier Ltd, 5(10), p. e02690. doi: 10.1016/j.heliyon.2019.e02690.

Shinnaranantana, N. (2019) 'Internet Shopping and Buying Behavior of Clothing and Accessories By Young Single Consumer in Bangkok, Thailand', in Proceedings of the 43rd International Academic Conference, Lisbon. International Institute of Social and Economic Sciences. doi: 10.20472/iac.2018.043.042. 
Swinker, M. E. and Hines, J. D. (2006) 'Understanding consumers' perception of clothing quality: A multidimensional approach', International Journal of Consumer Studies. doi: 10.1111/j.1470-6431.2005.00478.x.

Utz, S., Kerkhof, P. and van den Bos, J. (2012) 'Consumers rule: How consumer reviews influence perceived trustworthiness of online stores', Electronic Commerce Research and Applications. Elsevier B.V., 11(1), pp. 49-58. doi: 10.1016/j.elerap.2011.07.010.

Venkatraman, V. et al. (2012) 'New scanner data for brand marketers: How neuroscience can help better understand differences in brand preferences', Journal of Consumer Psychology. Society for Consumer Psychology, 22(1), pp. 143-153. doi: 10.1016/j.jcps.2011.11.008.

Weng, M. L. and Ding, H. T. (2014) 'Consumer acceptance and continuance of online group buying', Journal of Computer Information Systems, 54(3), pp. 87-96. doi: 10.1080/08874417.2014.11645707 